\title{
IDENTITAS GENDER DAN SEKSUAL SEBAGAI PERSONAL BRANDING PADA KONTEN TIKTOK LUCINTA LUNA
}

\author{
Joan Natasya Lambe ${ }^{1 *}$, Vega Ulfie Rahmawati² \\ ${ }^{1,2}$ Institut Komunikasi dan Bisnis LSPR, Jakarta, Indonesia \\ *joan.natasya.lambe@gmail.com
}

Submitted: 08-09-2021, Revision: 08-12-2021, Accepted: 28-12-2021

\begin{abstract}
In this technological era, media plays an important role in building personal branding. Not only companies, but individuals also need strong personal branding to get people's attention. Lucinta Luna is one of the celebrities who use their gender and sexual identity to make content called "Khodam". It is interesting to study the use of gender and sexual identity as personal branding. The purpose of this study was to analyze the use of gender and sexual identity by Lucinta Luna after being released from prison. This study uses a qualitative descriptive approach with data collection techniques derived from 25 TikTok video content with the topic of "Khodam" which is Lucinta Luna's personal branding strength. Secondary data is obtained from documentation of collaborative content with other public figures and conventional media. The data were analyzed with eight concepts from Peter Montoya in building personal branding. The results of this study indicate that Lucinta Luna performs these eight concepts by prioritizing "Khodam" or a male voice that sometimes appears as a way to attract netizens' attention. Now Lucinta's image is considered more self-accepting, fun, and full of positive things.
\end{abstract}

Keyword: Personal branding, Lucinta Luna, TikTok, Gender and Sexuality Indentity

\begin{abstract}
Abstrak
Pada era teknologi seperti saat ini, media memegang peranan penting dalam membangun personal branding. Tidak hanya perusahaan, tapi individu juga membutuhkan personal branding yang kuat untuk mendapatkan atensi masyarakat. Lucinta Luna merupakan salah satu selebritas yang menggunakan identitas gender dan seksualnya untuk dijadikan konten yang bernama "Khodam". Fenomena ini menarik untuk diteliti dalam kajian pemanfaatan identitas gender dan seksual sebagai personal branding. Tujuan dari penelitian ini untuk menganalisis penggunaan identitas gender dan seksual yang dilakukan oleh Lucinta Luna setelah keluar dari penjara. Penelitian ini menggunakan pendekatan dekriptif kualitatif dengan teknik pengumpulan data yang berasal dari 25 konten video TikTok dengan topik "Khodam" yang menjadi kekuatan personal branding Lucinta Luna. Data sekunder didapat dari dokumentasi konten kolaborasi dengan tokoh publik lain dan media konvensional. Data dianalisis dengan delapan konsep dari Peter Montoya dalam membangun personal branding. Hasil dari penelitian ini menunjukkan bahwa Lucinta Luna melakukan delapan konsep tersebut dengan mengutamakan "Khodam" atau suara laki-laki yang kadang muncul sebagai cara dia menarik perhatian warganet. Kini citra Lucinta dianggap lebih menerima diri sendiri, menyenangkan, dan penuh hal-hal positif.
\end{abstract}

Kata Kunci: Personal Branding, Lucinta Luna, TikTok, Identitas Gender dan Seksualitas

\section{PENDAHULUAN}

Setiap individu pasti mempunyai personal brand yang berbeda-beda. Melalui personal brand seseorang bukan hanya bisa menciptakan persepsi di benak orang lain, tapi juga bisa meraih keuntungan seperti popularitas dan perkembangan karir. Seperti yang dilakukan public figure atau selebritis, mereka harus mengelola personal brand dan memastikan memberikan nilai melalui personal brandnya kepada orang lain (Keller, et.al., 2015). Pengelolaan personal brand disebut sebagai personal branding.

$$
\text { Speak \& McNally }
$$
menjelaskan bahwa ada tiga komponen utama yang menentukan kekuatan personal 
brand, yaitu: 1) Khas: dalam hal ini personal brand berarti mewakili sesuatu. Mereka punya sudut pandang. Artinya sebuah merek harus memiliki perbedaan dari yang lain dan unik; 2) Relevan: apa yang mereka perjuangkan terkait dengan apa yang dianggap penting oleh orang lain. Artinya ada kesesuaian keinginan dan kebutuhan antara pemilik merek atau brand dan target; 3) Konsisten: kepercayaan orang pada suatu hubungan berdasarkan konsistensi perilaku yang mereka alami atau amati. Artinya personal brand tidak bersifat permanen, tergantung pada tindakan, yang berpengaruh pada pandangan positif dan negatif orang lain terhadap diri seseorang (Speak \& McNally, 2011).

Socrates, filsuf terkenal dari Yunani mengatakan, "the way to gain a good reputation is to endeavor to be what you desire to appear", kalimat tersebut dapat diartikan bahwa kunci utama dalam melakukan personal branding adalah kemampuan mengidentifikasi tujuan utama apa yang kita inginkan dan ingin seperti apa kita dikenal.

Personal branding adalah untuk mengambil alih kontrol bagaimana orang lain mempersepsikan kita sebelum mereka melakukan kontak secara langsung (Montoya \& Vandehey, 2008). Selaras dengan pernyataan tersebut, Bill Lang menjelaskan personal branding sebagai sebuah citra diri yang dapat diproyeksikan dalam setiap tindakan dan bukan sesuatu yang palsu atau dangkal (Haroen, 2014).

Proses dalam personal branding kemudian menuntut adanya pemahaman terhadap diri sendiri. Pesan yang ingin disampaikan harus disesuaikan dengan karakter dari individu tersebut.

Perusahaan atau individu bisa menggunakan banyak tools yang ada di internet untuk membantu mereka dalam melakukan branding dan masyarakat juga memiliki kebebasan dan kemudahan untuk mengakses informasi yang diberikan. Dengan saluran dan pesan yang tepat, branding dapat dilakukan dengan lebih efisien.

Pada era yang dipenuhi dengan perkembangan teknologi dan new media seperti saat ini, melakukan personal branding menjadi sangat mudah. Media baru memungkinkan perusahaan untuk mencapai tujuan mereka dengan cara yang belum pernah terjadi sebelumnya (West \& Turner, 2018).

Penelitian mengenai penggunaan media sosial untuk personal branding, diulas dalam artikel jurnal yang berjudul Social Media and Personal branding of Gospel Musicians. Hasil penelitian tersebut menunjukkan bahwa platform media sosial dapat digunakan dengan cara yang beragam termasuk tujuan yang terkait dengan personal branding (Ochieng', Ndeta, \& Ndavula, 2020). Tarnovskaya (2017) menyatakan bahwa munculnya media sosial memungkinkan siapapun untuk bisa membagikan brand diri atau personal branding.

Pawar (2016) menyatakan bahwa personal branding membuka peluang yang lebih baik, pekerjaan yang lebih baik, relasi yang lebih baik, pengakuan industri yang lebih baik. Artinya meskipun apa yang ditonjolkan adalah hal yang penuh sensasi, namun sejauh personal branding dilakukan dengan baik maka akan memberikan keuntungan dalam pekerjaan, seperti pada selebritis. Beberapa selebritas di Indonesia juga melakukan Personal Branding. Salah satunya adalah penelitian mengenai Barbie Kumalasari yang mendidentikkan dirinya sebagai boneka Barbie hingga mendapat julukan 'Ratu Halu'. Walaupun mendapat banyak komentar positif dan negatif, Barbie berhasil mendapatkan popularitasnya melalui media sosial (Rubiyanto \& Fildyanti, 2021).

Lucinta Luna dan Barbie Kumalasari sama sama merupakan selebritis yang sensasional. Akan tetapi yang membedakan adalah ciri khas yang ditonjolkan oleh keduanya. Penelitian ini juga berbeda dengan penelitian sebelumnya, karena artikel ini 
melihat fenomena Personal Branding yang dibangun oleh Lucinta Luna pada media sosial TikTok.

Ayluna Putri atau yang lebih dikenal dengan nama panggung Lucinta Luna adalah seorang selebritas Indonesia yang memulai karirnya di dunia hiburan sebagai seorang penari dan penyanyi dalam grup "Duo Bunga" dengan goyangan populernya yang bernama "Goyang Kembang" pada tahun 2018 lalu. Kemunculan Lucinta Luna seringkali dikaitkan dengan isu transgender yang diduga merupakan jati diri sebenarnya sosok kelahiran 32 tahun silam tersebut. Sebelum memulai debutnya, Lucinta disebut juga sebagai salah satu peserta dalam acara Be A Man dengan menggunakan nama Cleo Vitri (Elnyora, 2020).

Kepopuleran Lucinta Luna makin meningkat pada tahun 2018-2019 sebagai seorang artis kontroversial dengan begitu banyaknya terpaan berita negatif terkait isu status gender miliknya. Tidak sedikit masyarakat yang menghujat Lucinta Luna di berbagai platform media sosial seperti Instagram dan Twitter.

Banyak netizen yang kurang suka karakter Lucinta Luna karena terlihat sombong dan tidak mau mengakui bahwa dirinya adalah seorang wanita transgender atau transpuan. Walaupun sebenarnya tidak ada kewajiban dari dirinya untuk mengakui akan identitas gender ataupun seksual yang dimiliknya.

Transgender dapat diartikan sebagai payung untuk individu yang berekspresi gender tidak sesuai dengan seksnya, contohnya transseksual, cross dresser, drag king dan drag queens. Sedangkan transseksual merupakan individu yang tidak mengikuti gender sesuai jenis kelamin saat ia dilahirkan, melakukan operasi atau intervensi hormon GLSEN (dalam Yudah, 2013).

Selain itu, istilah transpuan atau trans perempuan adalah transgender yang awalnya diidentifikasi sebagai laki-laki, kemudian ia merasa bahwa ia adalah seorang perempuan (laki-laki menjadi perempuan). Lalu identitas gender (Gender Identity) merujuk kepada persepsi diri individu sebagai seorang pria atau wanita (Halgin \& Whitbourne, 2010).

Disisi lain, identitas seksual lebih mengarah sebagai identifikasi yang berkaitan dengan pengetahuan objektif tentang apakah individu seorang pria atau wanita berdasarkan pada tipe-tipe alat kelamin yang dimilikinya (Semiun, 2006).

Lucinta Luna memang lebih dikenal sebagai selebritas yang tenar melalui jalur sensasi. Akan tetapi hal ini justru menjadi Personal Branding yang melekat pada Lucinta Luna hingga membuatnya menjadi selebriti terkenal di Indonesia.

Awal tahun 2020 lalu, Lucinta Luna tersandung kasus penyalahgunaan narkotika hingga harus mendekam di balik jeruji besi selama sekitar satu tahun. Pada proses hukum yang harus dijalaninya tersebut, identitas Lucinta Luna sebagai seorang transseksual akhirnya diungkapkan oleh Humas Pengadilan Negeri Jakarta Selatan seperti yang dituangkan di dalam artikel media online Liputan 6.com (Habibie, 2020).

Setelah keluar dari penjara pada bulan Maret 2021, Lucinta Luna menampilkan Personal Brand yang berbeda dari yang sebelumnya. Kini Lucinta tampil lebih kalem, elegan dan tidak suka mencari keributan atau sensasi seperti dulu. Banyak komentar masyarakat di berbagai platform media sosial memuji perubahan Lucinta Luna yang dinilai lebih menghibur dan menarik. Salah satunya di dalam akun media sosial TikTok Lucinta Luna.

Menariknya, bila semula lulusan Sekolah Teknik Mesin atau STM ini seringkali menyangkal akan kebenaran identitas gendernya, namun sejak dirinya keluar dari penjara, hal tersebut justru menjadi personal branding baginya. Meskipun dirinya tidak mengakui secara frontal akan statusnya sebagai seorang transseksual.

Melalui berbagai konten media sosial. Tayangan konten Lucinta Luna di Instagram, TikTok dan Youtube meraih banyak 
penonton yang secara langsung juga berkontribusi pada meningkatnya pendapatan Lucinta Luna. Peningkatan pemasukan ini terbukti dari rumah senilai 30 miliar yang ia beli cash dari hasil endorsement yang didapat.

Perubahan yang terjadi pada Lucinta Luna bisa disebut sebagai rebranding yang merupakan upaya untuk merubah citra dari suatu orang agar dapat berubah menjadi lebih baik (Munir, 2017). Dalam proses rebranding yang telah dilakukan, Lucinta juga menunjukkan bahwa dia seolah lebih menerima dirinya sebagai seorang transpuan dengan tidak malu mengeluarkan suara "lakilaki" di beberapa konten media sosial miliknya ataupun saat berkolaborasi dengan selebritas lain.

Keunikan pengemasan konten Lucinta Luna dapat dilihat dari penggunaan suara laki-laki yang dinamainya dengan istilah "Khodam". Bahkan istilah "Khodam" ini dijadikan sebutan bagi Lucinta Luna sendiri sebagai "Yang Punya Khodam Leluhur" di dalam profile akun media sosial TikTok miliknya. Hal inilah yang membuat masyarakat sangat terhibur dan memberikan penilaian positif pada perubahan Lucinta Luna.

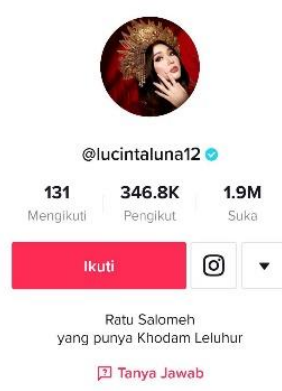

Gambar 1. Profile TikTok Lucinta Luna "Yang Punya Khodam Leluhur"

(Sumber: TikTok Lucinta Luna)

Pada akhirnya identitas gender dan seksual Lucinta Luna sebagai seorang transpuan yang suka mengeluarkan suara "Khodam" secara tiba-tiba dalam setiap penampilannya baik di media TV maupun konten media sosial, menjadi keunikan Personal Branding miliknya.
Hal ini sekaligus membuktikan bahwa Lucinta Luna menjadikan identitas gender dan seksualnya sebagai seorang perempuan transseksual adalah sebuah personal brand yang melekat pada dirinya.

Lucinta Luna berhasil mengelola personal brand tersebut, melalui proses yang dilakukan di dalam akun media sosialnya baik Instagram, TikTok, Youtube, dan juga dalam berbagai kolaborasi dengan selebritas lainnya ataupun ketika menjadi bintang tamu dalam acara TV.

Akan tetapi, dari hasil pengamatan peneliti, konten Lucinta Luna dengan menggunakan suara laki-lakinya paling banyak peneliti temukan di dalam akun TikTok miliknya yang cukup rutin dipublikasikan sejak bulan Juli 2021. Peneliti berhasil menemukan sebanyak 25 konten video TikTok Lucinta Luna yang menggunakan suara "Khodam" dan menyiratkan identitas gender Lucinta Luna di dalam video-video singkat, sehingga berhasil menarik perhatian publik.

Penggunaan media sosial yang tinggi di Indonesia, juga menjadi faktor pendukung kesuksesan pembentukan personal branding seseorang. Dalam survei yang dilakukan oleh Jakpat pada 2.321 responden di 33 propinsi Indonesia dan dimuat hasilnya oleh Kata Data (2021), media sosial TikTok menempati posisi keempat paling banyak digunakan oleh masyarakat Indonesia. Hasil survei tersebut membuktikan sebanyak $43 \%$ masyarakat di Indonesia menggunakan aplikasi TikTok.

TikTok merupakan platform yang menyerupai media sosial. Akan tetapi TikTok sendiri sebenarnya merupakan Content Distribution Platform. Di dalam akun TikTok seseorang bisa mencantumkan akun media sosial lainnya seperti Instagram ataupun Youtube (Praisra, 2019). Hal ini tentunya membantu proses personal branding seseorang, seperti yang dilakukan Lucinta Luna. 


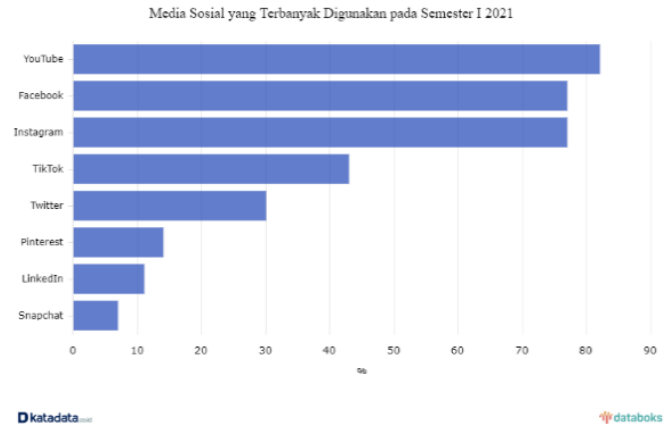

Gambar 2. Hasil Survei Tiktok Media Sosial Keempat Yang Paling Banyak Diakses Masyarakat Indonesia (Sumber: Kata Data)

Peneliti melihat fenomena yang terjadi pada Lucinta Luna sebagai suatu hal yang sangat menarik untuk diteliti dalam kajian pemanfaatan identitas gender dan seksual sebagai personal branding.

Tujuan dari penelitian ini adalah untuk menganalisis penggunaan identitas gender dan seksual yang dilakukan oleh Lucinta Luna selepas keluar dari penjara melalui konten pada akun media sosial TikTok dengan menggunakan delapan konsep pembentukan personal branding menurut (Montoya \& Vandehey, 2002), yaitu: (1) Spesialisasi (the law of specialization); memiliki ciri khas yakni ketepatan pada spesialisasi yang terkonsentrasi pada sebuah kekuatan, keahlian atau pencapaian tertentu yang dapat dilakukan melalui beberapa cara, yakni ability, behavior, lifestyle, mission, product, profession, dan service, (2) Kepemimpinan (the law of leadership); personal branding yang dilengkapi dengan kekuasaan, kredibilitas dan bisa memosisikan seseorang sebagai pemimpin yang sempurna, (3) Kepribadian (the law of personality) didasarkan pada sosok kepribadian yang baik, apa adanya, namun tidak harus menjadi sempurna, (4) Perbedaan (the law of distinctiveness); personal branding yang baik dan efektif perlu ditampilkan dengan cara yang berbeda, (5) Terlihat (the law of visibility); melakukan personal branding secara konsisten, terusmenerus dan dalam setiap kesempatan, (6)
Kesatuan (the law of unity); konsep ini menekankan bahwa kehidupan pribadi seseorang dibalik personal branding-nya harus sejalan dengan etika moral dan sikap yang telah ditentukan, (7) Keteguhan (the law of persistence); setiap personal branding membutuhkan waktu untuk tumbuh, dan selama proses berjalan, sangat penting untuk selalu memperhatikan setiap tahapannya, (8) Nama baik (the law of goodwill); jika ingin personal branding memberikan hasil yang lebih baik dan bertahan lama maka seseorang harus diasosiasikan dengan sebuah nilai atau ide yang diakui secara umum positif dan bermanfaat.

\section{METODOLOGI}

Penelitian ini menggunakan pendekatan deksriptif kualitatif. Menurut Creswell (2016) penelitian kualitatif adalah jenis penelitian yang mengeksplorasi dan memahami makna di sejumlah individu atau sekelompok orang yang berasal dari masalah sosial.

Metode riset pada penelitian ini menggunakan analisis isi yang merupakan Teknik sistematis untuk menganalisis isi pesan atau suatu alat untuk mengobservasi perilaku komunikasi dari komunikator yang dipilih (Kriyantono, 2006).

Terdapat lima tujuan dari analisis isi (Eriyanto, 2011), yaitu menggambarkan karakteristik dari pesan, menggambarkan secara detail isi (content), melihat pesan pada khalayak yang berbeda, melihat pesan dari komunikator yang berbeda, dan menarik kesimpulan penyebab dari suatu pesan.

Teknik pengumpulan data pada penelitian ini menggunakan sumber data yang berasal dari dokumen. Adapun data primer pada penelitian ini adalah 25 konten video TikTok dengan topik "Khodam" yang menjadi kekuatan personal branding Lucinta Luna. Sedangkan data sekunder berasal dari dokumentasi beberapa konten media sosial kolaborasi Lucinta Luna dengan tokoh publik lainnya serta media konvensional. 
Data tersebut kemudian dianalisis menggunakan delapan konsep pembentukan personal branding milik Montoya dan Vandehey.

\section{HASIL DAN PEMBAHASAN}

Seperti penjelasan yang telah dikemukakan pada bagian pendahuluan, bahwa membangun personal branding perlu adanya diferensiasi dan keunikan tersendiri. Oleh karena itu, penelitian ini akan menganalisis konten "Khodam" sebagai salah satu cara rebranding Lucinta Luna menggunakan identitas gender dan seksualnya sebagai konten yang bisa menghibur banyak orang.

Sesuai apa yang dijelaskan oleh Speak \& McNally (2011) tiga hal utama yang peneliti temukan di dalam personal brand seorang Lucinta Luna, yaitu:

1) Khas: Lucinta Luna sudah memenuhi elemen personal brand sebagaimana diutarakan Speak \& McNally (2011), yaitu unik, berbeda dan mewakili sesuatu hal. Lucinta Luna merupakan representatif dari seorang entertainer yang menonjolkan identitas gender dan seksualnya sebagai personal brand yang melekat pada dirinya. Meskipun memang terlihat penuh sensasi, akan tetapi harus diakui bahwa Lucinta sudah memapu memengaruhi benak publik, untuk terus mengingat bahwa seorang Lucinta Luna adalah sosok entertainer Indonesia yang identik dengan statusnya sebagai seorang transgender.

2) Relevan: artinya apa yang diperjuangkan oleh pemilik personal brand sesuai dengan targetnya. Melalui konten TikToknya Lucinta Luna terbukti sudah sangat memenuhi elemen ini. Terbukti dengan banyaknya respon positif warganet yang menerima perubahan diri Lucinta Luna menjadi sosok yang lebih terbuka atas identitasnya sebagai seorang transgender.

3) Konsisten: artinya personal brand tidaklah bersifat permanen, karena dipengaruhi oleh persepsi orang lain. Dalam hal ini, melalui 25 konten TikTok yang peneliti analisis, bisa ditemukan bahwa Lucinta Luna cukup konsisten untuk terus mendeklarasikan dirinya sebagai seorang transgender, meskipun tidak mengucapkannya langsung secara verbal. Akan tetapi penggunaan "Khodam" di dalam setiap konten-konten media sosialnya khususnya TikTok, menunjukkan bahwa personal brand Lucinta Luna betul-betul ditonjolkannya secara konsisten.

Akan tetapi sesuai dengan pernyataan di atas, personal brand tidaklah bersifat permanen, untuk itulah diperlukan pengelolaan melalui konsep personal branding (Montoya \& Vendehey, 2002) yang peneliti temukan di dalam 25 konten TikTtok Lucinta Luna berikut ini:

\section{Pembentukan Personal Branding Lucinta Luna}

Konsep dalam membangun personal branding yang baik menurut (Montoya \& Vandehey, 2002) adalah sebagai berikut:

\section{Spesialisasi (the law of specialization)}

Dari 25 video singkat yang diunggah di laman TikTok, Lucinta Luna peneliti menilai apa yang dilakukan Lucinta Luna menunjukkan dirinya menerapkan konsep Spesialisasi. Konsep ini berarti di dalam personal branding seseorang harus memiliki ciri khas yakni ketepatan pada spesialisasi yang terkonsentrasi pada sebuah kekuatan, keahlian atau pencapaian tertentu yang dapat dilakukan melalui beberapa cara, yakni ability, behavior, lifestyle, mission, product, profession, dan service

Lucinta Luna melalui konten TikToknya terlihat menunjukkan suatu ciri khas yang dimilikinya, yaitu suara laki-laki yang dia sebut sebagai "Khodam". Bahkan Lucinta juga terlihat menggunakan hashtag \#khodam \#khodamleluhur serta judul video yang mencantumkan istilah "Khodam" dalam setiap videonya.

Hal ini menunjukkan bahwa Lucinta melakukan konsep Spesialisasi melalui cara Ability dan juga Product. Ability artinya 
Lucinta Luna mempunyai kemampuan untuk menerapkan suatu sistem yang strategis untuk personal branding-nya melalui cara dengan menghasilkan Product, yaitu berupa konten video-video yang menunjukkan pesan tersirat mengenai identitas gender dan seksualnya sebagai seorang transseksual.

Apa yang dilakukan oleh Lucinta Luna ini juga sejalan dengan penjelasan Montoya \& Vendehey atas keorisinalan citra diri di dalam personal branding. Bahwa Personal branding bukanlah cara berpura-pura atau tidak menjadi autentik, juga bukan suatu hal yang manipulatif. Lebih dalam lagi dijelaskan bahwa personal branding adalah tentang menciptakan identitas eksternal individu sebagai sebuah proyek bisnis (Montoya \& Vendehey, 2002).

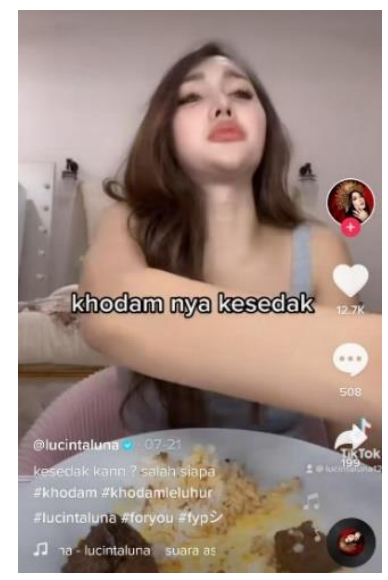

Gambar 3. Konten TikTok Lucinta Luna dengan Hashtag dan Judul "Khodam"

(Sumber: TikTok Lucinta Luna)

Sehingga konsep Spesialisasi yang diterapkan Lucinta Luna di dalam proses personal branidng melalui konten TikToknya, memang merupakan upaya Lucinta untuk menampilkan branding diri yang apa adanya dan tidak manipulatif. Selain itu peneliti melihat, hal ini juga merupakan upaya Lucinta Luna untuk menciptakan indentitas dirinya yang baru selepas keluar dari penjara, dalam konteks bisnis. Sehingga dirinya bisa menciptakan peluang baru melalui konten-konten media sosialnya yang diterima kembali oleh publik.

\section{Kepemimpinan (the law of leadership)}

Berarti personal branding yang dilakukan dilengkapi dengan kekuasaan, kredibilitas dan bisa memposisikan seseorang sebagai pemimpin yang sempurna (Montoya \& Vendehey).

Konsep ini dapat dilihat dari kemunculan Lucinta Luna dalam media sosial setelah keluar dari penjara. Dalam waktu hitungan bulan, terhitung sejak bulan Maret 2021, Lucinta berhasil eksis kembali di dalam dunia maya dan mendapat perhatian dari warganet.

Dari 25 video TikTok miliknya yang menunjukkan ciri khas suara "Khodam" menuai banyak "like" dari penonton. Jumlah "like" terbanyak bisa diperoleh Lucinta hingga mencapai 44,6 ribu "likes". Hal ini menunjukkan, meskipun dirinya menuai banyak kontroversi di dalam dunia hiburan tanah air, namun konten-kontennya yang memuat pesan tersirat akan status gender dan seksualnya, ternyata masih mendapat tempat di hati para warganet.

Selain itu, reaksi warganet yang tetap menerima Lucinta Luna melalui konten TikToknya, sejalan dengan pernyataan Deckers \& Lacy (2013), bahwa Personal branding merupakan respons emosional terhadap citra atau nama perusahaan, produk, atau seseorang. Respons ini bisa berupa perasaan suka, senang, cinta, takut, khawatir, atau marah, yang selalu berubah-ubah. Apapun yang diunggah seseorang di media sosial, harus memperlihatkan kebiasaan, karakter, kepribadian, dan minatnya. Informasi berupa teks, foto, dan video yang diunggah olehnya, merupakan cerminan personal brand yang ingin diketahui orang lain.

Dari pengertian tersebut, bisa disimpulkan bahwa Lucinta Luna memenuhi konsep Kepemimpinan (Montoya \& Vendehey, 2002), dikarenakan dirinya menampilkan konten media sosial TikTok yang memperlihatkan karakter diri Lucinta Luna secara apa adanya, sehingga kredibiltas Lucinta Luna diakui oleh warganet dan 
menimbulkan respon warganet yang menyukai karakter Lucinta Luna di dalam konten TikToknya. Hal inilah yang membuat Lucinta Luna bisa meraih perhatian warganet hanya dalam waktu hitungan bulan saja.

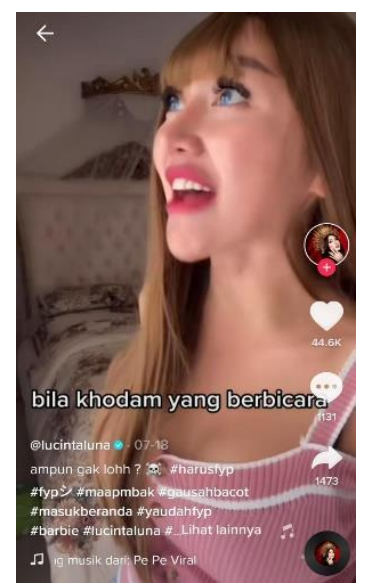

Gambar 4. Konten TikTok "Khodam” Lucinta Luna dengan Jumlah Like Terbanyak (Sumber: TikTok Lucinta Luna)

\section{Kepribadian (the law of personality)}

Montoya dan Vendehey (2002) menyebutkan bahawa konsep ini didasarkan pada sosok kepribadian yang baik, apa adanya, namun tidak harus menjadi sempurna.

Pada awal kemunculannya di dalam dunia hiburan tanah air, konsep ini memang tidak terlihat pada personal branding Lucinta Luna. Sekarang melalui konten TikTok-nya, Lucinta berhasil menunjukkan konsep ini.

Ciri khas suara "Khodam" yang dikemas dalam konten-konten TikTok menunjukkan keterbukaan atas identitas gender dan seksualnya meskipun tanpa harus ada pengakuan dari Lucinta Luna sendiri. Hal ini tentu saja memberikan efek positif bagi image Lucinta Luna yang dinilai warganet menjadi lebih terbuka, apa adanya dan jauh lebih lucu serta menghibur. Hal ini terlihat dari komentar-komentar yang diberikan pada video-video TikTok Lucinta yang menggunakan ciri khas suara "Khodam" miliknya.

Johnson (2018) menyatakan bahwa personal branding adalah tentang menjadi diri sendiri dengan lantang, bahkan ketika kita bertentangan dengan norma, membingungkan orang, membuat mereka penasaran hingga akhirnya bisa mengubah perspektif mereka.

Sehingga peneliti melihat konsep Kepribadian di dalam personal branding Lucinta Luna melalui konten TikToknya bisa terpenuhi, dikarenakan Lucinta Luna benarbenar menjadi dirinya yang apa-adanya, sehingga bisa menarik perhatian warganet kepada dirinya meskipun, ada catatan kelam di dalam perjalanannya sebagai seorang selebriti.

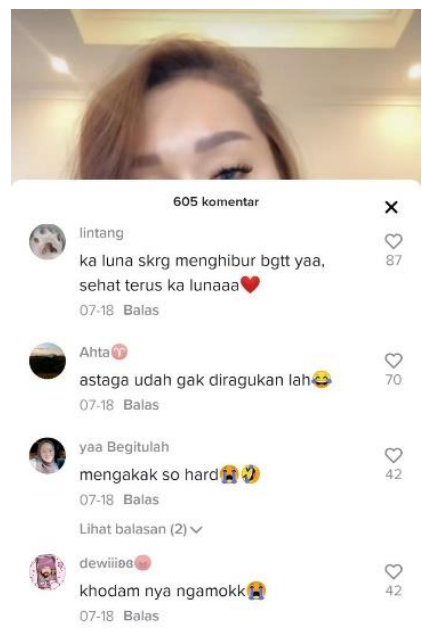

Gambar 5. Komentar Warganet Pada Konten TikTok "Khodam" Lucinta Luna (Sumber: TikTok Lucinta Luna)
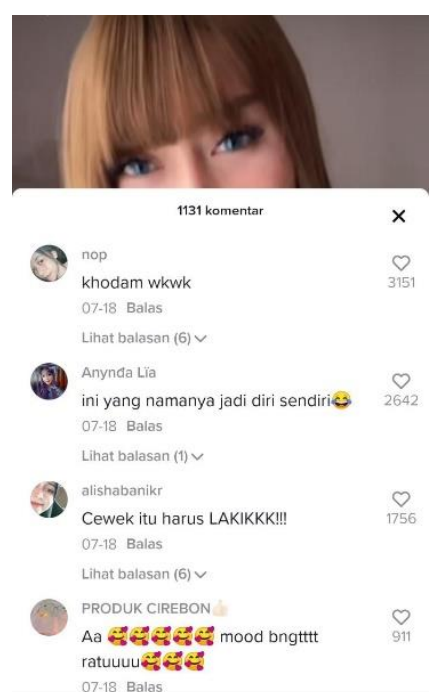

Gambar 6. Komentar Warganet Pada Konten TikTok "Khodam" Lucinta Luna (Sumber: TikTok Lucinta Luna) 


\section{Perbedaan (the law of distinctiveness),}

Sesuai dengan apa yang ditekankan oleh Montoya \& Vendehey (2002), bahwa personal branding yang baik dan efektif perlu ditampilkan dengan cara yang berbeda.

Maka konsep ini terlihat dalam proses personal branding Lucinta Luna melalui akun TikToknya yang menggunakan cara yang sangat berbeda.

Dari 25 video TikTok yang menggunakan suara "Khodam" di dalamnya, konsep setiap video tidak pernah serupa. Lucinta bisa mengunggah video saat dirinya sedang bersama rekan-rekannya namun di dalam video tersebut, terselip bagian dirinya yang mengeluarkan suara "Khodam".

Ada juga video yang menampilkan Lucinta menanggapi komentar warganet dan akhirnya mengeluarkan suara "Khodam". Selain itu, ada juga video di balik layar saat dirinya sedang melakukan shooting kolaborasi dengan selebritis Billy Syahputra dan juga mengeluarkan suara "Khodam". Cara Lucinta Luna mengemas ciri khasnya inilah yang menjadikan konsep personal branding yang dilakukannya menjadi berbeda dan menarik perhatian banyak warganet.

Arruda \& Dixson (2007) menyatakan bahwa, personal branding adalah tentang menggali atribut yang seseorang miliki seperti kekuatan, keterampilan dan kegemaran atau hasrat yang digunakan untuk menonjol dari orang lain. Lucinta Luna memang seperti tidak memiliki keahlian khusus dalam hal dunia seni, akan tetapi peneliti melihat bahwa kekuatan Lucinta Luna sehingga bisa menarik perhatian warganet terletak pada keahliannya untuk membuat konten-konten yang sarat dengan sensasi humor, meskipun harus menyertakan identitas gender dan seksualitasnya. Akan tetapi, hal ini sekaligus menjadi pembeda dan memenuhi konsep perbedaan di dalam personal branding seorang Lucinta Luna.

\section{Terlihat (the law of visibility)}

Membentuk personal branding yang kuat membutuhkan konsistensi. Dalam hal ini, Lucinta Luna secara terus-menerus menampilkan suara "Khodam" yang telah ia bingkai sedemikian rupa di setiap konten TikToknya agar masyarakat semakin terhibur dan menambah nilai jual diri dan endorsement yang ia dapat.

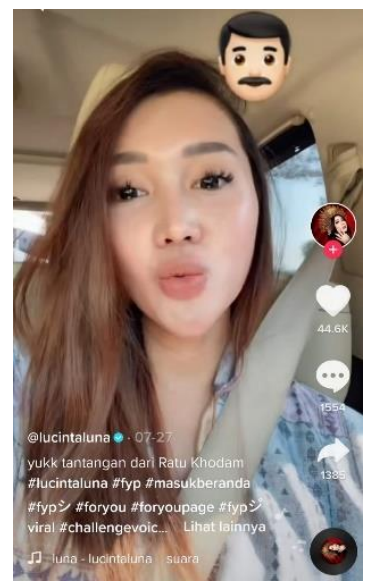

Gambar 7. Variasi 1 Konten TikTok "Khodam" Lucinta Luna

(Sumber: TikTok Lucinta Luna)

Pada video TikTok tersebut, Lucinta Luna membuat konten video yang menunjukkan lima macam suara, yaitu suara asli, suara kucing, suara anjing, dan suara laki-laki dengan menggunakan suara "Khodam". Selain itu, konten dengan menampilkan suara laki-laki dapat dilihat ketika Lucinta Luna acting menjadi Security, menjawab pertanyaan warganet, pura-pura digigit kucing, bernyanyi di depan umum, hingga menjawab pujian kalau ia cantik sambil tetap menunjukkan suara "Khodam".

Pembentukan personal brand dengan konsisten tentunya akan memunculkan citra baru di mata masyarakat. Citra dapat diartikan sebagai kesan seseorang atau individu tentang sesuatu yang muncul sebagai hasil dari pengetahuan dan pengalamannya (Suryanto \& Gassing, 2016). Jika dilihat dari faktor pembentuk citra, Lucina Luna menggunakan identitas fisik yang berupa suara "Khodam" untuk 
dijadikan ciri khas dirinya yang membedakan dengan orang lain.

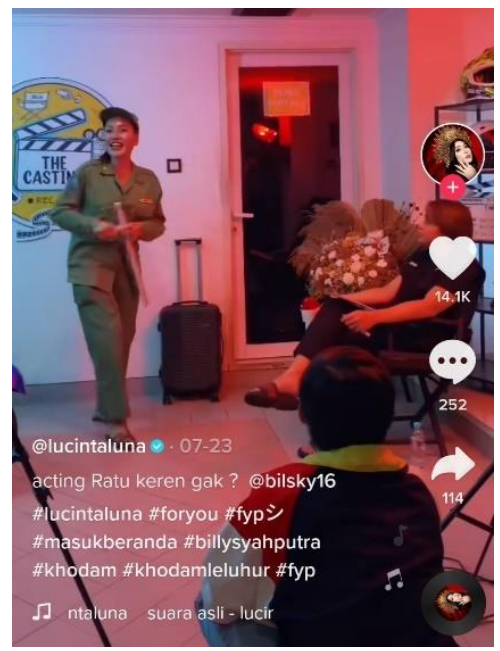

Gambar 8. Variasi 2 Konten TikTok "Khodam" Lucinta Luna

(Sumber: TikTok Lucinta Luna)

Duffy \& Hund dalam (Quick, 2021) menyatakan bahwa influencer mengalami apa yang disebut sebagai "visibility mandate" yang merupakan suatu keharusan untuk menempatkan diri di luar sana ke tingkat yang lebih tinggi yang secara langsung dikaitkan dengan metrik berbasis data, yaitu likes, followers, comments.

Dengan begitu Lucinta Luna juga banyak melakukan kolaborasi dengan selebritas lainnya. Hal ini dilakukan oleh Lucinta untuk mendapatkan spotlight yang lebih di internet sehingga banyak netizen yang membicarakan perubahan dalam dirinya.

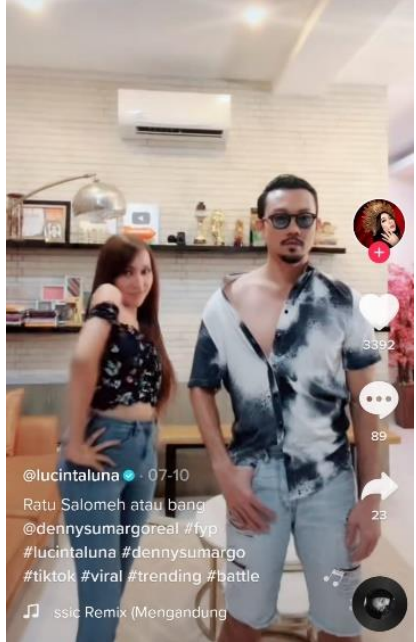

Gambar 9. Konten Kolaborasi dengan Denny Sumargo

(Sumber: TikTok Lucinta Luna)

\section{Kesatuan (the law of unity)}

Jika dulu sebelum masuk penjara Lucinta Luna merupakan sosok yang terlihat angkuh dan sombong, kini ia lebih banyak memperlihatkan sisi kemanusiaan dirinya dengan berbagi dengan masyarakat yang kurang mampu.

Kegiatan yang ia lakukan juga didokumentasikan di konten TikTok miliknya. Beberapa kali Lucinta masih mengeluarkan suara "Khodam" di dalam video tersebut. Dengan mengeluarkan suara tersebut, Lucinta seperti ingin menunjukkan bahwa dia sebagai salah satu selebritas dari komunitas LGBT juga mempunyai kepedulian yang tinggi pada masyarakat.

Tindakan Lucinta Luna ini diharapkan bisa merubah pandangan masyarakat yang kebanyakan tidak terlalu menghormati kelompok LGBT dan kebanyakan memandang kelompok tersebut dari sisi negatif. Konten berbagi ini juga membuktikan bahwa Lucinta Luna sedang membangun personal brand yang sejalan dengan etika moral.

Blackwell, et al., (2016) memaparkan bahwa banyak penelitian yang menemukan individu LGBT menggunakan media sosial untuk mengeluarkan tantangan yang mereka hadapi dalam kehidupan sehari-hari mereka 
seperti isolasi dan diskriminasi dari masyarakat.

Selaras dengan pernyataan sebelumnya, Vickery dalam (Mokhtar, Sukeri, \& Latiff, 2019) menjelaskan bahwa media sosial memberikan ruang untuk menyesuaikan diri, penerimaan, dan sirkulasi informasi. Oleh karena itu, media sosial banyak digunakan oleh komunitas LGBT untuk menyuarakan diri mereka untuk mendapatkan penerimaan dari masyarakat.

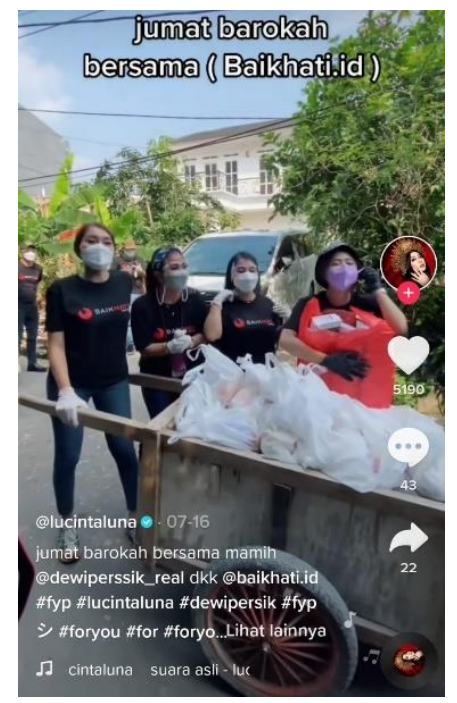

Gambar 10. Konten Berbagi Lucinta Luna (Sumber: TikTok Lucinta Luna)

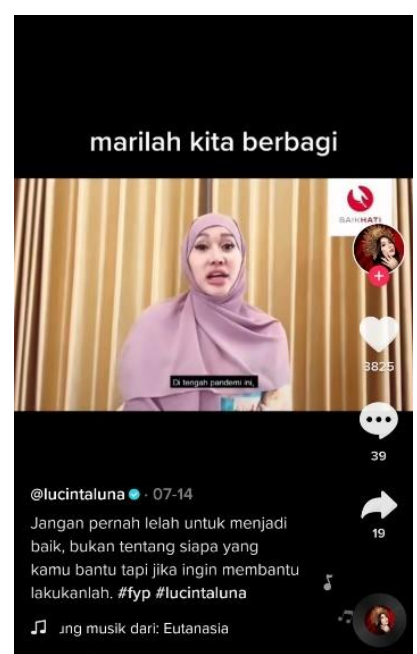

Gambar 11. Konten Berbagi Lucinta Luna

(Sumber: TikTok Lucinta Luna)

\section{Keteguhan (the law of persistence)}

Proses merupakan hal penting dalam membentuk personal branding yang kuat. Tidak mungkin ada personal branding yang dibentuk hanya dalam satu hari.

Lucinta Luna menyadari personal brand yang tertanam pada dirinya sebelumnya dipenuhi dengan hal negatif. Johnson (2017) memaparkan pentingnya seseorang untuk terus memantau personal brand dirinya sendiri di media. Oleh karena itu, Lucinta Luna mulai merubah cara dia melakukan engagement dengan warganet. Tidak lagi dengan menutupi jati dirinya, kini ia dengan terbuka menunjukkan bahwa benar dia adalah seorang transgender.

Perubahan personal brand yang dibawa oleh Lucinta Luna kini menunjukkan hasil yang sangat positif. Masyarakat banyak yang memuji dan terhibur akan konten yang ia berikan. Konsistensi Lucina Luna kini membuat dirinya terkenal sebagai Ratu "Khodam" dengan kelucuan suara lakilakinya yang dibalut oleh konten menarik yang ditunggu netizen.

Jika mengacu pada penjelasan Harris \& Rae dalam (Johnson, 2017), Ratu "Khodam" merupakan suatu personal branding statement yang memberikan seseorang kemampuan untuk membedakan dirinya dengan orang lain. 
Tabel 1. Komentar Netizen tentang Lucinta Luna

Sumber: TikTok Lucinta Luna

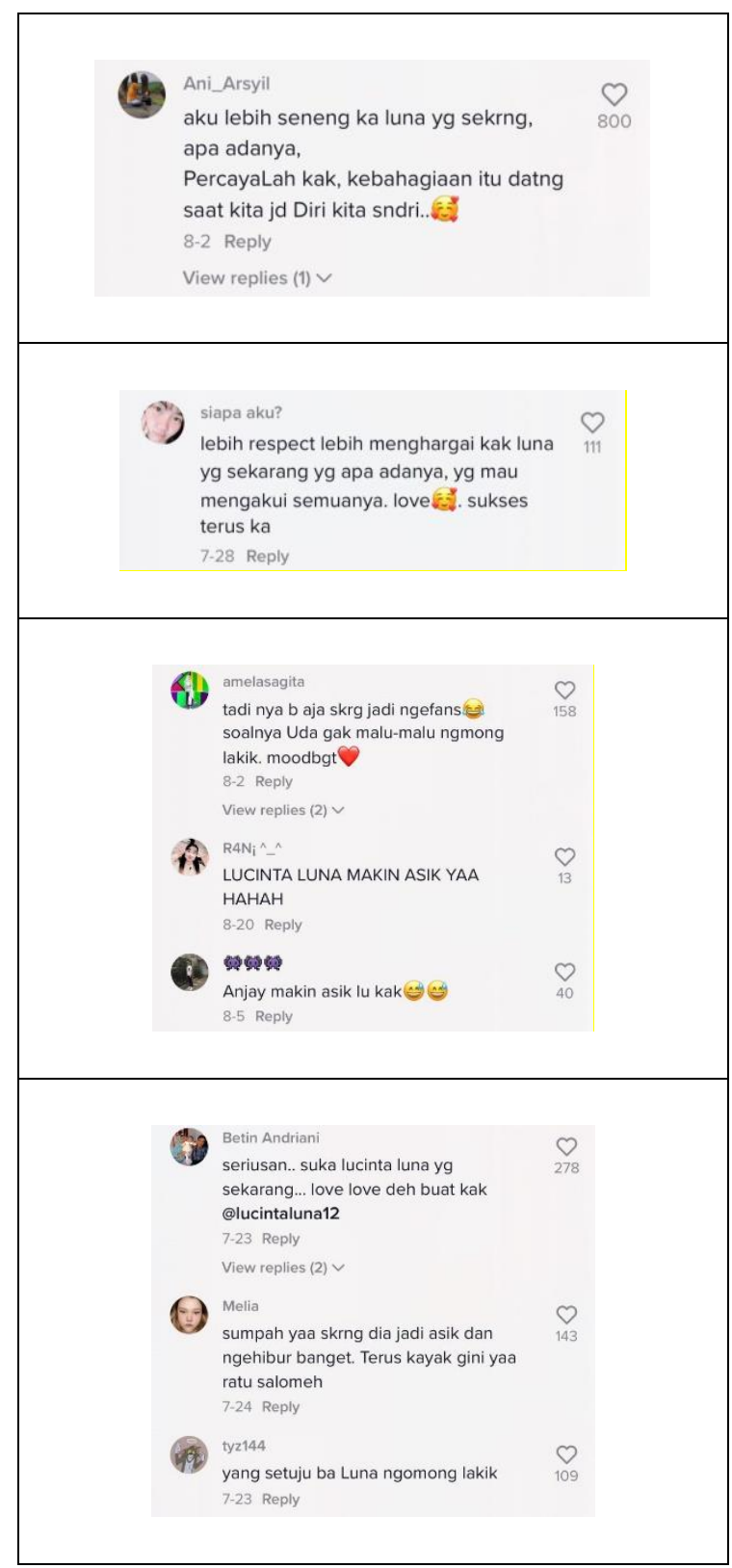

Nama baik (the law of goodwill)

Lucinta Luna berusaha untuk mempertahankan personal brand-nya lebih lama dan lebih baik dengan menunjukkan sisi positif seperti membaca ayat dari Quran dan mengajak netizen untuk selalu mengingat Tuhan YME. Konten seperti itu menunjukkan bahwa Lucinta Luna tidak hanya menampilkan konten yang menjual gender dan seksualitasnya saja. Tapi ia juga ingin masyarakat untuk mengetahui bahwa meskipun seorang transgender, Lucinta Luna juga merupakan Muslim yang taat.

Personal brand yang diciptakan Lucinta Luna tersebut juga berusaha untuk mengurangi ketidaksukaan masyarakat terhadap komunitas LGBT. Banyak sekali persekusi yang dilakukan kepada komunitas tersebut dan tidak banyak orang yang menghargai hak hidup mereka di Indonesia. Dalam hal ini, Lucinta Luna menjadi seorang sosok atau wajah dari komunitas LGBT yang ingin menunjukkan bahwa diri mereka pantas untuk dimanusiakan dan tetap menjalankan ibadah sesuai kepercayaan mereka terlepas dari pandangan masyarakat yang merasa bahwa mereka telah menyalahi agama.

Dari berbagai sumber pada artikelnya, Johnson (2017) menggarisbawahi bahwa self-awareness merupakan hal paling penting dalam membangun personal brand. Berkaitan dengan pernyataan tersebut, Lucinta Luna sudah sangat menerima dirinya sebagai seorang transgender, tidak seperti dulu ketika dia sering menyangkal di media sosial.

Dengan penerimannya itu, kini semakin banyak masyarakat yang lebih menyukai, berusaha memahami, dan bahkan beberapa mengidolakan Lucinta Luna.

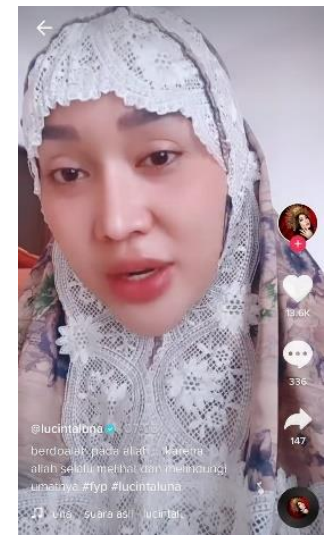

Gambar 12 Konten Keagamaan Lucinta Luna (Sumber: TikTok Lucinta Luna) 


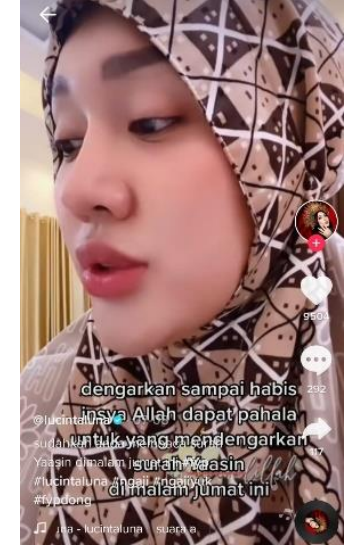

Gambar 13. Konten Keagamaan Lucinta Luna (Sumber: TikTok Lucinta Luna)

\section{SIMPULAN}

Berdasarkan hasil analisis yang telah dijabarkan, dari 25 konten TikTok Lucinta Luna yang ia unggah sejak keluar dari penjara, ditemukan 8 konsep utama dalam membangun personal branding sesuai dengan apa yang dijelaskan oleh (Montoya \& Vandehey, 2008).

Dalam membangun personal brand tersebut, Lucinta Luna memanfaatkan aspek identitas gender dan seksualitasnya yang dulu sebelum ia masuk penjara selalu dirahasiakan. Kini Lucinta jadi lebih menerima diri sendiri dengan mengeluarkan suara "Khodam" dan mengemasnya di berbagai konten TikTok yang mengundang ketertarikan banyak warganet.

Tidak hanya itu, Lucinta Luna juga banyak melakukan kolaborasi dengan pesohor lainnya untuk menambah nilai jual dirinya. Citra yang ditampilkan Lucinta Luna pun kini menjadi lebih positif dan disukai oleh banyak orang.

Identitas gender dan seksual seseorang adalah suatu hal yang bersifat pribadi dan tidak ada tuntutan untuk mendeklarasikannya. Akan tetapi sebagai seorang public figure di Indonesia, hal ini tentunya menjadi suatu perhatian bagi masyarakat luas. Untuk itu, alangkah baiknya bila apa yang ditampilkan kepada publik adalah karya dan prestasi di dunia hiburan Indonesia dan bukan sensasi semata.
Sehingga apa yang dilihat publik dari sosok seorang Lucinta Luna dan selebritis lainnya adalah karya bukan identitas gender ataupun seksual seseorang.

\section{DAFTAR PUSTAKA}

Annur, C. M. (2021, September

1). Masyarakat Indonesia Paling Banyak Akses YouTube Pada Semester I-2021. Retrieved from Kata Data: https://databoks.katadata.co.id/datap ublish/2021/09/05/masyarakatindonesia-paling-banyak-aksesyoutubepada-semester-i-2021

Arruda, W., \& Dixson, K. (2007). Career Distinction: Stand Out by Building Your Brand. John Wiley \& Sons.

Blackwell, L. H. (2016). LGBT Parents and Social Media: Advocacy, Privacy, and Disclosure during Shifting Social Movements. Proceedings of the 2016 CHI conference on human factors in computing systems, 610622. doi: $10.1145 / 2858036.2858342$

Creswell, J. W. (2016). Design Pendekatan Kualitatif, Kuantitatif, dan Mixed. Yogyakarta: Pustaka Pelajar.

Deckers, E., \& Lacy, K. (2013). Branding Yourself: How to Use Social Media to Invent or Reinvent Yourself. Que Publishing.

Elnyora, S. (2020, February 25). Parapuan. Diambil kembali dari Surya Malang Tribun

News: https://suryamalang.tribunnews.com /2020/02/25/biodata-lucinta-lunadan-latar-belakang-kehidupannyasetelah-identitasnya-sebagai-cowokterbongkar

Eriyanto. (2011). Analisis Isi: Pengantar Metodologi Untuk Penelitian Ilmu Komunikasi dan Ilmu Sosial Lainnya. Jakarta: Kencana.

Habibie, N. (2020, Februari 13). Liputan 6 News. Diambil kembali dari Liputan 6.com: https://www.liputan6.com/news/rea 
d/4178272/lucinta-luna-resmi-gantikelamin-desember-lalu-beginiceritanya

Halgin, R., \& Whitbourne, S. (2010). Psikologi Abnormal (Perspektif Klinis Pada Gangguan Psikologis). Jakarta: Salemba Humanika.

Haroen, D. (2014). Personal Branding: Kunci Kesuksesan Anda Berkiprah di Dunia Politik. Jakarta: PT Gramedia Pustaka Utama.

Jhonson, C. (2018). Platform: The Art \& Science of Personal Branding. New ork: Lorena Jones Books.

Johnson, K. M. (2017). The Importance of Personal Branding in Social Media: Educating Students to Create and Manage their Personal Brand. International Journal of Education and Social Science, 21-27. Diambil kembali dari https://www.researchgate.net/public ation/313256001_The_Importance of_Personal_Branding_in_Social_M edia_Educating_Students_to_Create _and_Manage_their_Personal_Bran

Keller, K. r., A.M.G, \& Jacob, I. (2015). Strategic Brand Management: Building, Measuring, and Managing Brand Equity (Fourth). Pearson India Education.

Kriyantono, R. (2006). Teknik Praktis Riset Komunikasi. Jakarta: PT. Kencana Perdana.

Mokhtar, M. F., Sukeri, W. A., \& Latiff, Z. A. (2019). Social Media in Propagating Influence on Spreading LGBT Movements in Malaysia. Proceeding of The 5th Conference on Communication, Culture and Media Studies, 267-274. Diambil kembali dari

https://journal.uii.ac.id/CCCMS/arti cle/view/12637/9124

Montoya, P., \& Vandehey, T. (2002). The Personal Branding Phenomenon. United States of America: Personal Branding Press.
Montoya, P., \& Vandehey, T. (2008). The Brand Called You: Make Your Business Stand Out in a Crowded Market Place. USA: McGraw-Hill.

Munir, M. (2017). Strategi Rebranding JX International Surabaya Dalam Upaya Membangun Brand Trust Dan Brand Loyalty Pelanggan Surabaya (ID). Universitas Islam Negeri Sunan Ampel. Diambil kembali dari http://digilib.uinsby.ac.id/15438/

Ochieng', A. A., Ndeta, W., \& Ndavula, O. J. (2020). Social Media and Personal Branding of Gospel Musicians in Kenya. African Multidisciplinary Journal of Research (AMJR), 5(1). Diambil kembali dari https://www.researchgate.net/public ation/344467357_Social_Media_an d_Personal_Branding_of_Gospel_ Musicians_in_Kenya

Pawar, A. (2016). The Power of Personal Branding. International Journal of Engineering and Management Research, 840-847. doi:https://doi.org/10.32509/wacana /v20i1.1253

Praisra, H. (2019, October 14). TikTok bukan media sosial loch. Diambil kembali dari Republika: https://www.republika.co.id/berita/g aya-

hidup/trend/19/10/14/pzciyc328tiktok-bukan-media-sosial-lho

Quick, T. (2021). \#GaysOverCOVID: The Social Drama of LGBTQ Representation on Instagram. International Journal of Communication, 4934-4955. Diambil kembali dari https://ijoc.org/index.php/ijoc/article /view/16959

Rubiyanto, \& Fildyanti, M. (2021). Personal Branding Barbie Kumalasari Untuk Meraih Popularitas Melalui Instagram. WACANA: Jurnal Ilmu Komunikasi,

25-40. 
doi:https://doi.org/10.32509/wacana .v20i1.1253

Semiun, Y. (2006). Kesehatan Mental. Yogyakarta: Kanisius.

Speak, K. D., \& McNally, D. (t.thn.). Be Your Own Brand: Achieve More of What You Want by Being More of Who You Are. Diambil kembali dari ReadHowYouWant.com

Suryanto, \& Gassing. (2016). Public Relations. Yogyakarta: Graha Ilmu.

Tarnovskaya, V. (2017). Reinventing Personal Branding Building a Personal Brand Through Content on Youtube. Researchleap Journal of International Business Research and Marketing, 3(1). Diambil kembali dari https://ideas.repec.org/a/mgs/jibrme/ v3y2017i1p29-35.html

West, R., \& Turner, L. H. (2018). Introducing Communication Theory (Analysis and Application). New York: McGraw-Hill Education.

Wimmer, R., \& Dominick, J. (2011). Mass Media Research an Introduction (1). Australia: Wadsworth Publishing Company.

Yudah, A. A. (2013). Representasi Transgender dan Transeksual dalam Pemberitaan di Media Massa: Sebuah Tinjauan Analisis Wacana Kritis. Jurnal Kriminologi Indonesia, 37-49. 